\title{
RESENHA
}

\section{Congresso Internacional Lusófono sobre Esoterismo Ocidental (Ciencias de las Religienes, Universidad Lusófona de Humanidades e Tecnologías, Lisboa, Portugal, 2016)}

Otávio Santana Vieira

Doutorando em Ciências das Religiões/PPGCR/ Universidade Federal da Paraíba. Membro do Centro de Estudios sobre el Esoterismo Occidental de la UNASUR. Correo electrónico: otavio.filosofia@gmail.com

DOI: http://dx.doi.org/10.15517/rehmlac.v8i2.27249

Fecha de recibido: 8 de octubre de 2016 - Fecha de aceptación: 2 de noviembre de 2016

Ocorreu em Lisboa, Portugal, entre os dias 7 e 10 de Maio de 2016, o primeiro Congresso Lusófono Sobre Esoterismo Ocidental, tendo como organizador a Universidade Lusófona de Humanidades e Tecnologias. Seu coordenador geral foi o Prof. Rui Lomelino de Freitas, coordenador da linha de investigação em Esoterismo Ocidental do Curso de Ciências das Religiões desta instituição. Contou com o apoio do departamento de História da Filosofia Hermética e Correntes Correlatas (History of Hermetic Philosophy and Related Currents) da Universidade de Amsterdã.

O evento em seu caráter pioneiro deve ser primeiramente levado em consideração, pois a área de investigação Esoterismo Ocidental vem se desenvolvendo substancialmente em língua portuguesa. Contudo, o evento contou com participantes de língua inglesa, espanhola, francesa, italiana, entre outras, em meio um bom número de inscritos. Ocupando um espaço de representatividade nesta área de investigação, trouxe uma proposta temática central envolvendo a importante questão da definição e da delimitação da disciplina (ou campo como alguns preferem) no âmbito da academia.

As atividades se desenvolveram principalmente em português, espanhol e inglês. Destaco a conferência de abertura do Prof. Peter Forshaw (Universidade de Amsterdã) sobre as diferentes propostas de investigação, apresentando cada uma suas implicações epistemológicas. O Prof. Forshaw, substituindo magistralmente o Prof. Wouter Hanegraaff, que por questões pessoais não pode estar presente, desenvolveu a proposta do colega Hanegraaff acerca do Esoterismo Ocidental entendido analogicamente como um software e seus upgrades: esoterismo 1.0, esoterismo 2.0 e esoterismo 3.0. Esta proposta que considero de sucesso nos é útil para entender o nível de desenvolvimento das abordagens sobre Esoterismo Ocidental. O tema da conferência estava em consonância ao tema do evento e apresentou de forma clara o desenvolvimento das propostas de abordagem e definição de Esoterismo na academia. 
Outra atividade magnífica foi uma visita a esplendida Biblioteca do Palácio Nacional de Mafra e a aula com o Prof. Peter Forshaw sobre a importante obra de Heinrich Khunrath Amphitheatrum Sapientiae Aeternae, aula que transcorreu com a competência neste quesito e o notável bom humor do Prof. Forshaw.

Acerca das atividades nos Simpósios Temáticos (STs) destaco como os mais importantes em volume e qualidade dos trabalhos apresentados os STs "Arte e Esoterismo Ocidental", "Estudos Junguianos" e "Estética, Simbólica e Esoterismo". Todos contaram com boas colaborações científicas em suas áreas específicas e possibilitando a percepção acerca do desenvolvimento e qualidade das pesquisas destas temáticas em língua portuguesa e espanhola.

O evento também contou com a participação de membros de grupos esotéricos que participaram de STs e estiveram presentes nas demais atividades, aproximando estes e o discurso acadêmico. Este matiz ficou bastante claro quando das palavras do Prof. Rui Lomelino de Freitas na conferência de encerramento acerca da delimitação acadêmica do evento e sua abertura para ouvir os grupos esotéricos no ambiente da academia, permitindo a colaboração, interação e a escuta entre ambas as partes.

Havia uma pequena feira de livros, entre obras de referência sobre o tema geral do evento, havia livros de divulgação escritos por autores portugueses, como o Prof. Rui Lomelino de Freitas e o Prof. José Manuel Anes. Porém, ainda seguem tímidas as obras de divulgação científica e de teses e dissertações sobre Esoterismo Ocidental em língua portuguesa.

De maneira geral, acredito que este evento foi paradigmático para os pesquisadores da temática em língua portuguesa, e ibero-americano como um todo, em termos de abertura do espaço acadêmico para discussão e um bom nível de organização e estrutura física para comportá-lo. O apoio dos colegas de Amsterdã também se insere com um dos pontos favoráveis para o sucesso do evento, o que demonstra que as pesquisas sobre Esoterismo Ocidental se desenvolve em um bom ritmo no continente europeu e na América latina. Parabenizo os organizadores e a Universidade Lusófona de Humanidades e Tecnologias pelo agradável evento, a ótima acolhida dos congressistas e pela estrutura disponível e interesse nestas temáticas. Ficamos no aguardo do próximo Congresso Lusófono Sobre Esoterismo Ocidental que há de se repetir com certeza. 


\section{Anexo 1 \\ Programa \\ Congresso Lusófono Sobre Esoterismo Ocidental}

Conferência de Abertura com o Prof. Peter Forshaw.

Simpósios Temáticos (STs):

- Arte e Esoterismo Ocidental - Grupo A: Artes Visuais;

- Arte e Esoterismo Ocidental - Grupo B: Poesia, Cinema, Animação, Música e Simbólica;

- Esoterismo, Religiões Místico-esotéricas e Ciência;

- Estética, simbólica e esoterismo;

- Estudos Junguianos: O Homem moderno em busca da Alma;

- Franco-maçonaria e Esoterismo;

- "Gnosis": Cristianismo gnóstico; Hermetismo e Neoplatonismo: as Raízes do Esoterismo na Antiguidade;

- Hermetismo, Pitagorismo e Platonismo como forças motrizes do Renascimento e da Ciência Moderna;

- Nas raízes do esoterismo ocidental: o laboratório grego;

- New Age e o Esoterismo Ocidental;

- Raízes e Horizontes do Gnosticismo Português;

- Rosacruz, Teosofia Cristã e Ciências Arcanas;

- Teosofia Antiga e Moderna.

Mesas-redondas:

- "Estudos acadêmicos em Gnose e Esoterismo: que futuro?" (José Manuel Anes, Ricardo Lindemann (UnB/UFJF), Paulo Mendes Pinto (ULHT) e Rui Lomelino de Freitas (ULHT));

- “Utopia e Realização" (Annabela Rita (Inst. de Língua Portuguesa Luís de Camões), Paulo Mendes Pinto (ULHT) e Mendo de Castro Henriques (Un. Católica)).

Conferência de Encerramento com o Prof. Rui Lomelino de Freitas.

Visitas guiadas:

- Assembleia da República (Símbolos iluministas);

- Palácio Nacional de Mafra, distrito de Lisboa (visita a Biblioteca do Palácio de Mafra/Aula com o Prof. Peter Forshaw);

- Museu Maçônico Português (Visita/Jantar). 